\title{
ANALYZING THE TOURIST BEHAVIOR OF THE INTERNATIONAL STUDENTS IN WARSAW
}

\author{
Petrică NIȚOAIA* \\ “Alexandru Ioan Cuza" University of Iași, Faculty of Geography and Geology, Bd. Carol I, no. 20A, 700505, Iași, \\ Romania, e-mail: petricanitoaia@yahoo.ro \\ Gabriel CAMARĂ \\ “Alexandru Ioan Cuza” University of Iași, Faculty of Geography and Geology, Bd. Carol I, no. 20A, 700505, Iași, \\ Romania, e-mail: gabriel.camara@uaic.ro
}

Citation: Camară, G., \& Nițoaia, P. (2020). Analyzing the Tourist Behavior of the International Students in Warsaw. Analele Universitătii din Oradea, Seria Geografie, 30(2), 167-175. https://doi.org/10.30892/auog.302106-842

\begin{abstract}
This paper is the result of a case study on the foreign students from Warsaw (winter semester 2015-2016), their view on the city and their behavior as tourists. In this case study we applied a questionnaire and analyzed the resulting data in SPSS in order to understand why the students chose Warsaw, if they were involved in tourist activities and if the tourist market from the city and beyond can satisfy their needs. This paper may be useful for policymakers in cities with large numbers of foreign students since it highlights the needs and relation of foreign students regarding tourism.
\end{abstract}

Key words: international students, educational tourism, tourist behavior, geostatistics, quantitative methods

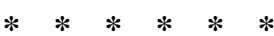

\section{INTRODUCTION}

Ever-increasing, tourism is becoming more important and our society views the act of travelling as a way of attaining relaxation, finding fulfilment in life and also getting to know one's self better. The youth tourism (Horak and Weber, 2000) and the youth travel market becomes so important from the 1990s that it was discussed into the first WTO's International Conference on Youth Tourism, held in New Delhi, 1991 (Abdel-Ghaffar et al., 1992).

The tourist behavior is analyzed in many research articles from many points of view (Afshardoost and Eshaghi, 2020; Ferreira Silva et al., 2020; Huang et al., 2020; Jiménez-Barreto, 2020; Manosuthi et al., 2020; Tkaczynski et al., 2020; Wang et al., 2020; Xue and Zhang, 2020; Kock and Ringberg, 2019; Kock, Josiassen and Asssaf, 2018; Kumar, 2016; Lin and Kuo, 2016; Pearce, 2016), but students' tourist behavior not, with some exceptions (Tran et al., 2018; Pereira 
López, 2016), which is why we considered this article useful in the context of student mobility is the maximum, at least in European countries. For students, all the above reasons to travel are increased by their energy and many times their desire to acquire knowledge - the knowledge production is also considered a tourist attraction (Travesi, 2017), especially cultural knowledge. Thus, there is a need to understand their behavior, in order to create satisfying travel offers.

Since tourism is already difficult to define (WTO), including students in the category of tourists poses even greater difficulties. However, in certain cases, students (or pupils) do become tourists, hence the concept of educational tourism (García-Rodríguez and Mendoza Jiménez, 2015; Pitman et al., 2011; Pawlowska and Roget, 2009), or international academic tourism (Bento, 2014). Certain interesting cases appear when educational activities (cultural/school exchange programs, field trips) are regarded as tourist activities, this happening because the trip is necessary for the study process. Summarizing, educational tourism means the travel activity of people with the main goal of accumulating knowledge (Pawlak, 2015).

The concentration of foreign students in cities (Michael et al., 2004) is justified by the offer provided by the urban environment: "Towns and cities provide the context (...) where tourism, leisure and entertainment form major service activities. These environments also function as meeting places, major tourist gateways, accommodation and transportation hubs, and as central places to service the needs of visitors" (Hall and Page, 2006, p. 222).

According to WTO, young people travel in order to increase their knowledge about the world, to experience and understand different cultures and, at least $70 \%$ of them, in order to study and travel in other countries. Thus, they participate in the tourism process. Other sources tell the same thing (Abdullateef and Biodun, 2014) adding that many times the statistical image is false or difficult to understand. Even so, studies on this have been done (Pawlak, 2015), with results that encourage the goals of this paper such as showing that foreign students travel more than local ones; three types of the most common of those travels being observed: spontaneous travel, organized travels and study abroad (such as Erasmus+).

\section{MATERIALS AND METHODS}

This paper aims at understanding the tourist behavior of foreign students in Warsaw, the Capital city of Poland. Accordingly, it will show how students behave when they consider themselves tourists, if they used their time in Warsaw for tourist activities and if they went out of the city for tourism. The data concerning tourism and the total number of students in Warsaw was obtained from the Statistical Yearbook of the city of Warsaw or from the web-page of the Statistics Poland. However, the raw data is not telling anything about the tourist experience of those students. Since this paper aims at offering a view of that experience, this was done by analyzing the questionnaire answers of 50 foreign students, present in Warsaw in the spring of 2016.

For data analysis we used Cluster analysis and ANOVA in SPSS. Cluster Analysis is "an exploratory analysis that tries to identify structures within the data. Cluster analysis is also called segmentation analysis or taxonomy analysis. More specifically, it tries to identify homogenous groups of cases if the grouping is not previously known" (Statistics Solutions, 2018). ANOVA, or Analysis of Variance, "is used for examining the differences in the mean values of the dependent variable associated with the effect of the controlled independent variables, after taking into account the influence of the uncontrolled independent variables" (Statistics Solutions, 2018).

Here, the sample numbered 50 foreign students which answered an online questionnaire (Note 1) disseminated through social media platforms (Facebook) and e-mail. A sample is a collection of measurable objects, individuals or data selected by the study conductor in a random or specific way (Asandului, 2002). The size of this sample is small because it is limited by the lack of access to data regarding the status of foreign students, the questionnaire being applied in the circle of known students. Since the language used for the questionnaire was English, it is visible that the respondents from Ukraine and Belarus are a minority, the great majority of respondents being from the European Union (EU) countries. Concerning the nationality, three of the respondents didn't specify theirs. As 
of those who did, only one of them comes from a country at the Equator (Indonesia) hence the others are from the northern hemisphere. It should also be noted that the big proportion of respondents from East-European and Balkan countries is explained by the close trade and political relations between Poland and those countries. Half of the respondents were Erasmus+ students while the others were receiving a scholarship from the Polish government or where exchange students (other programs). More than half $(56 \%)$ chose to study in Warsaw because they could travel to Poland while $42 \%$ because of academic opportunities. From a different point of view, 69\% of the respondents studied in Warsaw at the time of the research while the other $40 \%$ already finished their studies in the city. As for the length of their study stay, $46 \%$ studied in the city for more than one semester, $26 \%$ where there for full degree length while just one respondent spent less than one month in the city.

Financially, $42.9 \%$ answered that they received parental funding during their stay in Warsaw, as their main income source, 32.7\% declared their scholarship as their principal revenue. Regarding gender, $61 \%$ where females, the rest were males and one chose not to answer the question regarding sex. Finally, we have to separate the 49 respondents who gave details about their income sources into two groups, $42 \%$ which were supported by parents and $32 \%$ which benefited from scholarships while the other smaller group were either working or using their savings. Among the respondents, $34.8 \%$ had a monthly income varying between $€ 90$ and $€ 499$, $48.8 \%$ had access to incomes varying between $€ 499$ and $€ 999$ while the other $13.9 \%$ had access to sums larger than $€ 1000$. Bearing in mind that the living costs in Warsaw are smaller than in western European capitals (from authors own experience, more than $€ 300$ suffice for accommodation and food, especially if the students live in university subsidized hotels), we can safely assume that many foreign students are using their surplus income in tourist activities.

\section{RESULTS AND DISCUSSIONS}

In order to understand the influence of tourism in a certain area, one of best way to do so is by using the benchmarking technique (Heely, 2011; Hot spots, 2012), which means comparing two or more similar administrative entities from the point of view of important tourist statistical indicators; such as bed-nights, number of tourists and tourism profit. Maybe surprisingly for a city destroyed so many times during its history, the tourism sector of Warsaw is growing year on.

With more than eight million visitors in 2016, the city became the most visited from Poland, even if there is a big competition in the country. In Figure 1 is a comparison that shows how the only real competitor for Warsaw is Krakow, from the point of view of tourism. A useful tourism research was made for another big Polish city, Poznan (Kotus et al., 2015). For a more accurate image of the tourism evolution of Polish cities see a work complete with time series and a beautifully designed synthetic indicator for measuring tourism development of the country's cities, among which Warsaw (Majewska, 2011). As for the whole Europe, the city is trying to become important in a very competitive regional city tourism area, with cities like Wien and Prague that it has to look up to. However, statistically, the city was ranked 43rd on a global level and on the $14^{\text {th }}$ place in the EU on a scale comparing the total number of tourists visiting the cities (Geerts, 2016).

Warsaw is the Capital city and among the most important economic regions of Poland, and one of its major functions is that of an academic center. According to European Commission (European Commission - Study in Europe - Country Profile - Poland, 2015), in 2014 there were 1.46 million students in Poland out of which more than 223000 in Warsaw.

In the same year, overall, there were about 55000 foreign students in the country, of which 16628 in the Capital. Looking at the last years (Figure 2), it can be seen a downfall of the total number of students in Warsaw, probably caused by the general demographic decline of the country and by increasing academic importance of other Polish cities, such as Krakow.

However, an opposite trend is presented by the foreign students in Warsaw, which grew from a share of just $2 \%$ in $2010 / 2011$ to over $7 \%$ in $2015 / 2016$. Unfortunately, there were no data available as to determine the nationalities of the foreign students from Warsaw but, looking at a national level, it can be seen that the Ukrainians and Belarusians are the dominating groups, partly 
explained by the economic and historic ties of the two countries with Poland and by the similarity of their languages with Polish.

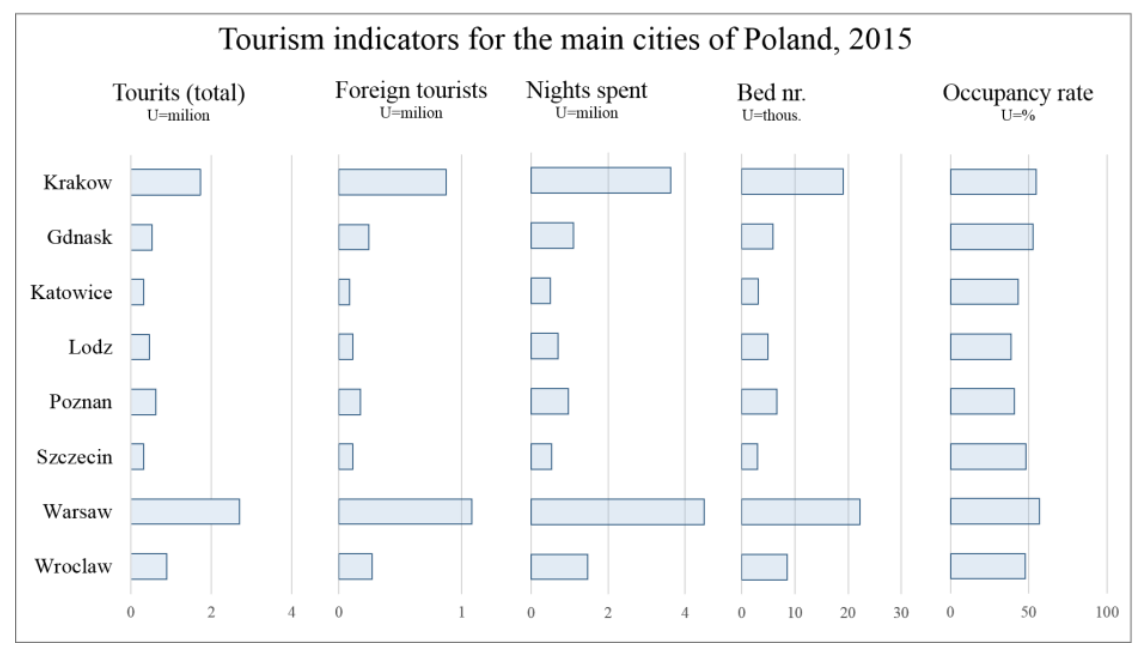

Figure 1. Comparison of tourism indicators between Warsaw and the next seven most important Polish cities (Data source: BDL, 2015)

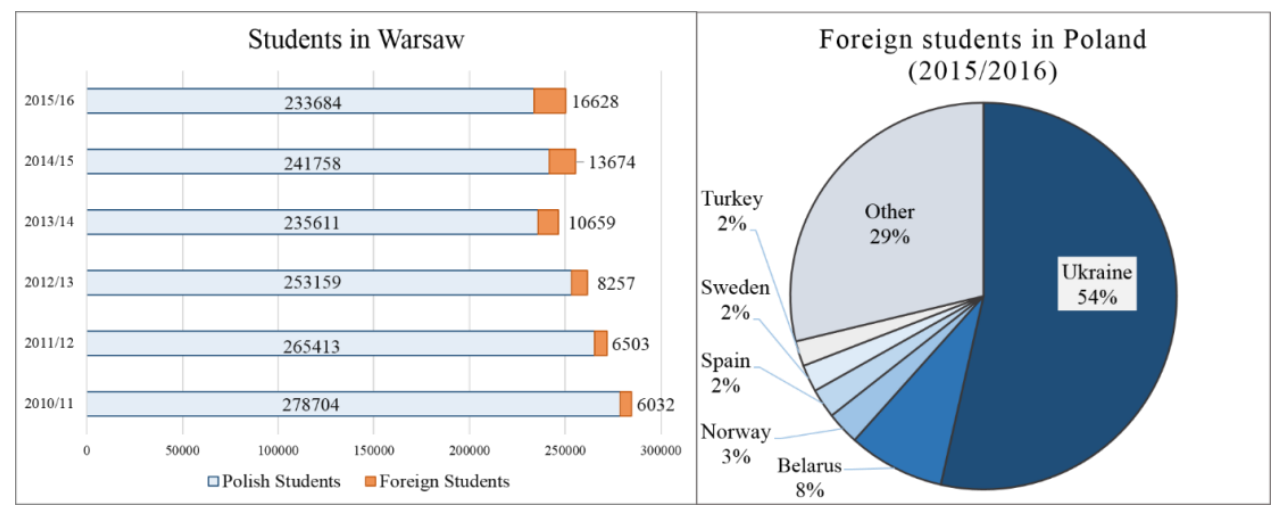

Figure 2. The situation of local and foreign students in Warsaw (Data source: http://studyinpoland.pl/, Statistical Yearbook of Warsaw)

The real identity of Warsaw differs from the one shown through the main tourist info site (Warsawtour.pl) (Lange, 2012). He insists on the modern and cultural side of the city as opposed to the unclear image promoted by the site. A different approach shows that all the information sources are contributing to the creation of the city's image while the tour-operators are the ones focusing on culture (Dudek-Mankowska, 2009). The foreign students in Warsaw associated the city with communism and winter before their stay while, during or after their stay, that image improved to one of a green city, full of culture, nightlife but still dominated by the communist Palace of Culture. In order to determine the above-mentioned aspects, the questionnaire begun with inquiries regarding which features they associated the city with prior to arrival (they were able to choose between the following options which were offered based on literature and the city image communicated by official marketing means: Winter, Summer, Second World War (II WW), Communism/Sad Urban Landscape, Old Town, Night Life/Bars, Sky Scrapers, Palace of Culture and Science, Jewish Warsaw/Ghetto, Green areas, Chopin, Museums). Most of them associated the city with Winter 
(82\%) and II WW, Communism, Old Town and Chopin (all having been selected by about 50 to $60 \%$ of the respondents). However, when asked at the end of the questionnaire if they associate the city with the same features as they did prior to their arrival, their feedback was different, a very big share of the respondents ( $80 \%$ or more) now associated the city with: The Palace of Science and Culture, Chopin, Green areas, Night Life, Sky Scrapers and II WW. Out of them, the most prominent symbol was the Palace of Science and Culture, due to its central position, dominating the city's CBD. The symbol that saw the most significant growth was represented by Sky Scrapers whiles the Communism and related fell drastically. Green Spaces, museums and Chopin are all symbols that grew in importance for students. All these show the developing efforts of Warsaw in order for the city to have a friendlier image and also the interests and activities of the foreign students.

Tackling the most important matters, 56\% of the respondents chose Warsaw for studying because of travel possibilities while $72 \%$ considered themselves also tourists and not only students (Table 1) during their stay in the capital of Poland. Also, the longer the stay, the less those students identified themselves as tourists (after one semester). Since so many of the respondents regarded themselves as tourists, this is the most important feature that gives this research a positive tone, hence its aim to discover the student's tourists needs and behavior.

Table 1. Correlation table between the length of studies and perception as tourists (Data source: own data)

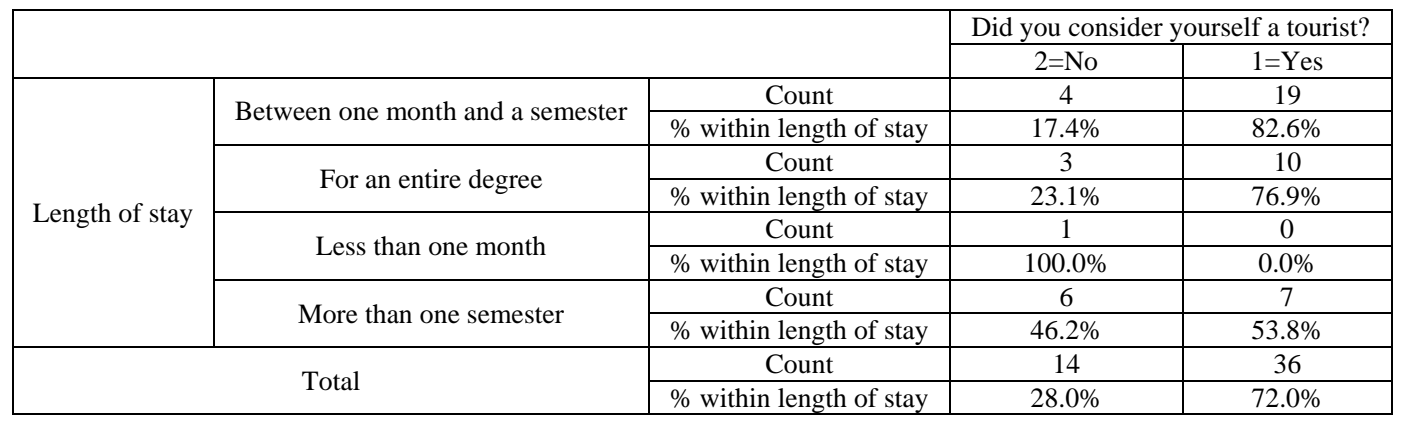

Regardless of the duration of their stay, $72 \%$ of the foreign students considered themselves tourists. However, looking at this perception from different time categories about $80 \%$ students spending between one month and one semester in Warsaw (and those enjoying full degree studies in the city) considered themselves tourists, while among the ones that spent more than one semester but less than a full degree time in the city only half of them had a self-perception as tourist. We can assume that the time spent in a foreign city, does not highly influence student's perception as being also a tourist or not; however this idea must be tested on a bigger statistical population.

Even if the language was a barrier for some of the respondents, the majority had a good interaction with the local people and a good opinion about the town, 90\% would return as tourists, while half just for work. Thus, $77 \%$ of the students enjoyed traveling around the city and the nightlife, $65 \%$ were attracted by cultural tourism while most of the female respondents enjoyed shopping in the city. Taking all these into account it becomes no wonder that so many of the students considered themselves tourists while in Warsaw.

When analyzing the relationship between the total income of the students and their view on the affordability of Warsaw (Figure 3) we cannot identify any visible correlation and thus we can conclude that the perception on affordability is a purely subjective one. On the other hand, when asked, the foreign students had ideas as to how the city can serve them better, from a tourist point of view. Those were: organizing more concerts, English should be more widely spoken (many students would like the Polish people to be friendlier with using the English language), more cycling paths and a friendlier attitude of locals towards foreigners (this, however, has to do with the language barrier since very few of the poles born before the 1990s speak English). 


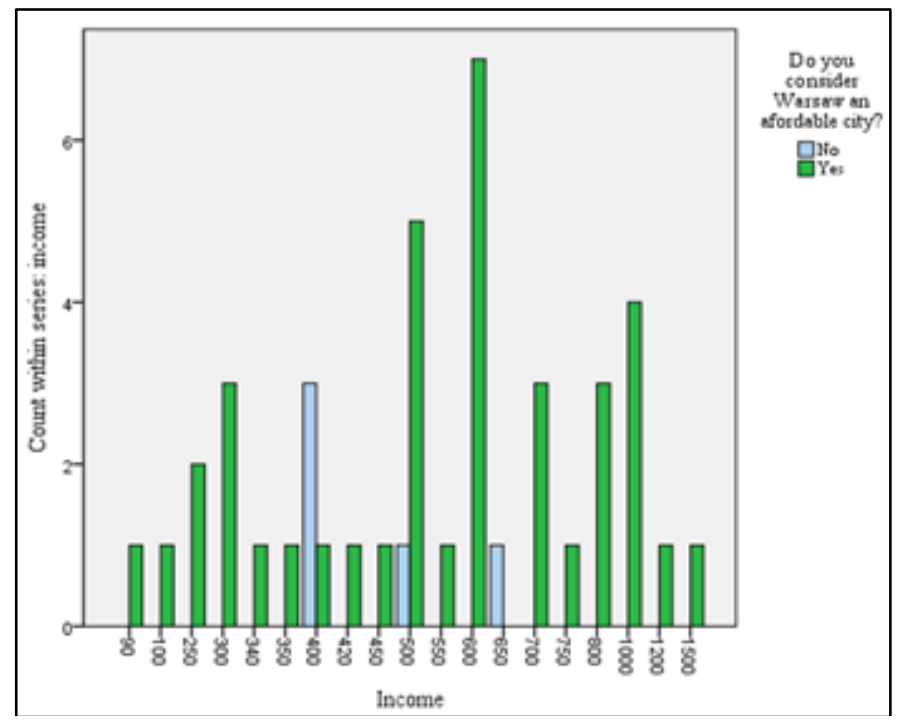

Figure 3. Correlation between incomes and affordability of Warsaw city (Data source: own data)

Even if at the start of their stay in Warsaw, the foreign students didn't perceive the city as it wanted to be perceived which is: modern, friendly, smart and full of history (Lange, 2012; DudekMankowska, 2009); during their stay and after, the foreign students saw the city as it is marketed or very close to that but, still marked by the communist scars which are to found especially in the architecture. Summing up, the image of the city is a positive one, with only one important thing to improve, which is the locals' attitude towards the English language

Students are a very mobile social group (Abdullateef and Biodun, 2014), and the foreign students from Warsaw do not differ. Over $90 \%$ of the respondents used Warsaw as a starting point for traveling to other parts of the country while $78 \%$ travelled from the city to other parts of Europe.

As the below representation shows (Figure 4), the most visited destinations where those closer to Warsaw, especially in the V4 group. However, it can be seen long distance travels also, the most probable reason for their occurrence being family visits. On the other hand, a connection between the length of stay in Warsaw and the distance students travelled was spotted, with the longer stays translating into journeys on longer distances.

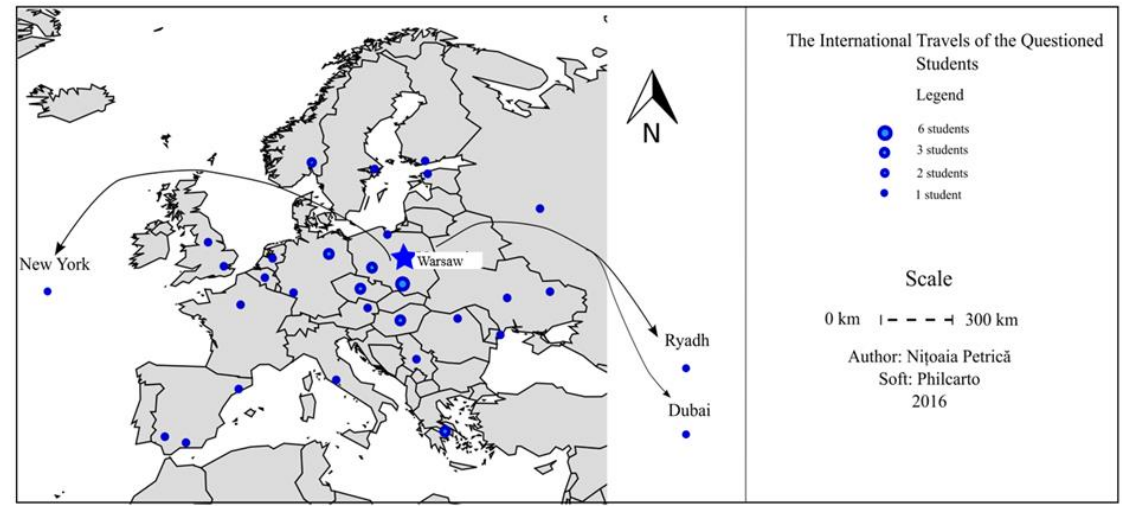

Figure 4. Cities where the foreign students travelled to, starting from Warsaw (Data source: own data) 
Regarding financial aspects of the their stay in Warsaw, 92\% of the questioned ones declared that they spent money on tourist activities, which is somewhat not surprising since $72 \%$ of them considered themselves tourist. Out of the respondents, $70 \%$ appreciated how much they spent monthly on tourist's activities. These can be further divided into three categories: more than half of them spent less than $150 €$ monthly on tourism, $25 \%$ spent between 140 and $300 €$ on tourism while the rest spent more (with two very high sums appearing: $900 €$ and $2000 €$, though this might be as a result of misunderstanding the question). All these numbers must be completed by the fact that $88 \%$ of the respondents regard Warsaw as an accessible city, from a financial point of view. We can thus safely assume that the foreign students visiting Warsaw have a lot of disposable income which they can use for tourist's activities, especially since living in the city is not a great financial burden for the most.

\begin{tabular}{|c|c|c|c|c|c|}
\hline \multicolumn{7}{|c|}{ ANOVA } \\
\hline & $\begin{array}{c}\text { Sum of } \\
\text { Squares }\end{array}$ & df & Mean Square & F & Sig. \\
\hline Between Groups & 45027210.210 & 22 & 2046691.373 & .820 & .669 \\
\hline Within Groups & 29941813.333 & 12 & 2495151.111 & & \\
\hline Total & 74969023.543 & 34 & & & \\
\hline
\end{tabular}

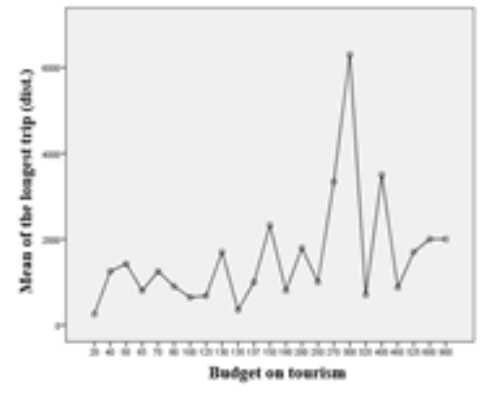

Figure 5. ANOVA test and correlation matrix

(Data source: own data)

By utilizing the ANOVA test (Baloglu, 1997), we intended to show if the students' incomes are somehow influencing their tourist behavior (Figure 5). Four different tests were done but the budget for tourism didn't influence the tourist decisions of students (as to how much time they spend on tourism or the distance they travelled). The distribution of incomes compared with the affordability of the city for students could not be correlated so their incomes did not pose a great stress on their experience. The results are explained by the fact that the students as a group, are travelling proportionally more than other human groups, in spite of their incomes, while also not spending a lot at the destination (Pawlak, 2015).

A profile of the respondents was created through the Cluster Analysis, in which their relation to the tourist offers accessed in Warsaw was analyzed. The indicators used were the following (derived from questionnaire questions): tourist offers were easily accessible, tourist offers for students, longest trip in distance, and longest trip in days and income. The analysis was made with SPSS using the Two Step Cluster option.

Since the first two indicators were categorical, they were the most important while the last three which, though not being so important for the final resulting cluster, serve well for the purpose of understanding the final result.

Group description:

1. $45.5 \%$ is a middle way group which had access to tourist offers, had medium incomes and enjoyed a medium travel time.

2. $21.2 \%$ is the least numerous group, made out of students which had no problem finding tourists offers targeting them, with high incomes and long journeys.

3. $33.3 \%$ is a group made out of students which travel above the average while not having access to student targeted tourist offers.

We can thus appreciate that the foreign students from Warsaw travelled regardless of incomes or targeted tourism offer, travelled and enjoyed their time in Warsaw, as tourists. However, those who had access to offers designed for students generally travelled more and used those offers. 


\section{CONCLUSION}

The foreign students that chose Warsaw in 2016 view themselves as tourists and their behavior is in accordance with that view. Both in the city and outside it, they did take the chance to discover the most they could during their study time, regardless of their incomes or time spent there. Though they do have access to some tourist offers designed for them it is clear that the city should do more to satisfy their demand for tourist activities. Given the existing Erasmus mobility program and other academic programs, local policies must profit from this opportunity and be oriented also to the satisfaction of this segment of tourists.

Despite the obvious limitations of this research (the lack of access to some data, the sample research is not statistically significant), we believe that other studies, improved, including larger ones, can be carried out on this model, the more so as the tourist behavior of the students it has not been analyzed in other research works.

\section{Notes}

(1) - Link to the on-line questionnaire: https://drive.google.com/open?id=1vhPVyhBgD09So4ZVYvBiBIIEnPZCqYeL.

\section{REFERENCES}

Abdel-Ghaffar, A., Handy, M., Jafari, J., Kreul, L., \& Stivala, F. (1992). Conference reports: Youth tourism. Annals of Tourism Research, 19(4), 792-795. https://doi.org/10.1016/0160-7383(92)90069-2

Abdullateef, A. O., Biodun, A. B. (2014). Are international students tourists?. International Journal of Business and Globalisation 1, 13(3), 298-306. https://doi.org/10.1504/IJBG.2014.064677

Afshardoost, M., Eshaghi, M. S. (2020). Destination image and tourist behavioural intentions: A meta-analysis. Tourism Management, 81 (2020). https://doi.org/10.1016/j.tourman.2020.104154

Asandului, L. (2002). Statistica turismului. Aplicații [Tourism statistics. Applications], Junimea, Iasi (in Romanian).

Baloglu, S. (1997). The relationship between destination images and sociodemographic and trip characteristics of international travellers. Journal of vacation marketing, 3(3), 221-233. https://doi.org/10.1177/135676679700300304

BDL (1995). Bank Danych Lokalnych. Retrieved Decembrie 12, 2015, from http://stat.gov.pl/bdlen/app/strona.html?p_name=indeks

Bento, J. P. C. (2014). The determinants of international academic tourism demand in Europe. Tourism Economics, 20(3), 611-628. https://doi.org/10.5367/te.2013.0293

Dudek-Mankowska S. (2009). Warsaw's destination image. In W. WIlk (Ed.), Global Changes: Their Regional and Local Aspects (pp. 187-195). Warsaw: University of Warsaw-Faculty of Geography and Regional Studies.

European Commission (2015). Study in Europe - Country Profile - Poland. Retrieved from https://ec.europa.eu/education/study-in-europe/country-profiles/poland_en

Ferreira Silva, F. J. et al. (2020). Is the spending behaviour of tourists affected by low-cost carriers' operation? Some empirical evidence. Tourism Management Perspectives, 33 (2020). https://doi.org/10.1016/j.tmp.2019.100630

García-Rodríguez, F. J., Mendoza Jiménez, J. (2015). The role of tourist destination in international students' choice of academic center: the case of erasmus programme in the Canary Islands. PASOS. Revista de Turismo y Patrimonio Cultural, 175-189.

Geerts, W. (2016). Euromonitor International, Top 100 City Destinations Ranking. Retrieved from http://observatorituristic.aralleida.com/ftp/documents/Estadistiques/M\%C3\%A9s\%20estudis\%20d\%C2\%B4altres\%20organismes/ 0002.-\%202017\%20Top\%20100\%20Cities\%20Destinations\%20Final\%20Report\%20Euromonitor.pdf

Hall, C. M., \& Page, J. S. (2006). The Geography of Tourism and Recreation, $3^{\text {rd }}$ edition, London and New York: Routlege.

Heely, J. (2011). Iside City Tourim: An European Perspective (Part of the "Aspects of Tourism" Series ed.). Channel View Publications.

Horak, S., Weber, S. (2000). Youth tourism in Europe: Problems and prospects. Tourism Recreation Research, 25(3), $37-$ 44. https://doi.org/10.1080/02508281.2000.11014923

Hot spots (2012). Benchmarking global city competitiveness. Retrieved from Economist Intelligence Unit: https://www.citigroup.com/citi/citiforcities/pdfs/eiu_hotspots_2012.pdf

Huang, X., Li, M., Zhang, J., et al. (2020). Tourists' spatial-temporal behavior patterns in theme parks: A case study of Ocean Park Hong Kong. Journal of Destination Marketing \& Management, $15 \quad(2020)$ https://doi.org/10.1016/j.jdmm.2020.100411

Jiménez-Barreto, J. et al. (2020). Linking the online destination brand experience and brand credibility with tourists' behavioral intentions toward a destination. Tourism Management, $79 \quad$ (2020) https://doi.org/10.1016/j.tourman.2020.104101 
Kock, F., Josiassen, A., \& Asssaf, A. G. (2018). On the origin of tourist behavior. Annals of Tourism Research, 73 (2018), 180-183. https://doi.org/10.1016/j.annals.2018.04.002

Kock, F., Ringberg, T. (2019). Embodied cognition effects on tourist behavior. Annals of Tourism Research, 78 (2019). https://doi.org/10.1016/j.annals.2019.05.002

Kotus, J., Rzeszewski, M., \& Ewertowski, W. (2015). Tourists in the spatial structures of a big Polish city: Development of an uncontrolled patchwork or concentric spheres? Tourism Management, 50, 98-110. http://dx.doi.org/10.1016/j.tourman.2015.01.007.

Kumar, V. (2016). Examining the role of destination personality and self-congruity in predicting tourist behavior. Tourism Management Perspectives, 20, 217-227. http://dx.doi.org/10.1016/j.tmp.2016.09.006.

Lange, M. (2012). Warsaw City Brand - developing a brand positioning for Warsaw to increase its appeal. Retrieved from http://studenttheses.cbs.dk/bitstream/handle/10417/3238/marcel_lange.pdf?sequence=1

Lin, C., Kuo, B. (2016). The Behavioral Consequences of Tourist Experience. Tourism Management Perspectives, 18, 8491. http://dx.doi.org/10.1016/j.tmp.2015.12.017.

Majewska, J. (2011). The measurment and evaluation of tourism development in polish cities in the last decade comparison of Poznan with the biggest cities in Poland. In G. Gołembski, Determinants of Tourism Development in Urban Destinations and Methods of Tourism Measurment (pp. 33-59). Poznań: Wydawnictwo Uniwersytetu Ekonomicznego w Poznaniu.

Manosuthi, N., Lee, J.-S., \& Han, H. (2020). Impact of distance on the arrivals, behaviours and attitudes of international tourists in Hong Kong: A longitudinal approach. Tourism Management, 78 (2020). https://doi.org/10.1016/j.tourman.2019.103963

Michael, I., Armstrong, A., \& King, B. (2004). The travel behavior of international students: The relationship between studying abroad and their choice of tourist destinations. The Journal of Vacation Marketing, 10(1), 57-66. https://doi.org/10.1177/135676670301000106

Pawlak, A. (2015). Demand side of international students tourism market. Case of Umeå - Sweden. Umeå: Umeå Universitet.

Pawlowska, E., Roget, F. M. (2009). Una aproximación al impacto económico directo del turismo académico: El caso de los intercambios Erasmus en la universidad de Santiago de Compostela [An approach to the direct economic impact of academic tourism: The case of Erasmus exchanges at the University of Santiago de Compostela]. Revista Galega De Economía, 1-20.

Pearce, P. (2016). Australian contributions to tourist behaviour studies. Journal of Hospitality and Tourism Management, 26, 84-90, https://doi.org/10.1016/j.jhtm.2016.01.004

Pereira López, X. (2016). The economic impact of international students in a regional economy from a tourism perspective. Tourism Economics, 22 (1), 125-140. https://doi.org/10.5367/te.2014.0414.

Pitman, T., Broomhall, S., \& Majocha, E. (2011). Teaching ethics beyond the academy: Educational tourism, lifelong learning and phronesis. Studies in the Education of Adults, 4-17.

Statistics Solutions (2018). Retrieved from Anova in SPSS: https://www.statisticssolutions.com/anova-in-spss/

Statistics Solutions (2018). Retrieved from Cluster Analysis: https://www.statisticssolutions.com/cluster-analysis-2/

Study in Poland - Over $57 \quad 119$ international students in Poland. (2015). Retrieved from http://www.studyinpoland.pl/en/index.php/news/43-over-57-119-international-students-inpoland\#: :targetText=There\%20are\%2057\%20119\%20international,\%2C\%20in\%202015\%20\%2D\%203.1\%25).

Tkaczynski, A., Rundle-Thiele, S., \& Truong, V. D. (2020). Influencing tourists' pro-environmental behaviours: A social marketing application. Tourism Management Perspectives, 36 (2020). https://doi.org/10.1016/j.tmp.2020.100740

Tran, M., Moore, K., \& Shonec, M. (2018). Interactive mobilities: Conceptualising VFR tourism of international students. Journal of Hospitality and Tourism Management, 35, 85-91.

Travesi, C. (2017). The politics of knowledge as a tourist attraction. Annals of Tourism Research, 130-139. http://dx.doi.org/10.1016/j.annals.2017.07.014

Wang, C. et al. (2020). Examining the dimensions and mechanisms of tourists' environmental behavior: A theory of planned behavior approach. Journal of Cleaner Production, $273 \quad$ (2020). https://doi.org/10.1016/j.jclepro.2020.123007

Xue, L., Zhang, Y. (2020). The effect of distance on tourist behavior: A study based on socialmedia data. Annals of Tourism Research, https://doi.org/10.1016/j.annals.2020.102916

Submitted:

February 15, 2020
Revised:

July 07, 2020
Accepted and published online

Octomber 08, 2020 